\title{
Transformation of the Ghent System in Sweden: Silent Institutionalization of Complementary Unemployment Benefits'
}

\section{Jayeon Lindellee ${ }^{2}$}

Postdoctoral Researcher, Lund University, School of Social Work, Sweden

\begin{abstract}
The Swedish public unemployment insurance program is characterized by its governance structure involving union-linked insurance funds, famously known as the Ghent system. This paper argues that the unions' strongly entrenched interest in the provision of unemployment benefits has continued to shape the establishment and expansion of complementary benefits for the unemployed in multiple forms, including bilateral Employment Transition Agreements between employers' organizations and unions (occupational pillar) and privately provided complementary income insurance benefits mediated by unions (private pillar). The paper accounts for this multi-pillarization process of the Swedish unemployment benefit provision system and how the unions' involvement has come to take multiple forms. The paper also discusses distributive implication of this union-led development of the complementary pillars, which reinforces the differences in risk protection between different occupational groups and sectors.
\end{abstract}

\section{KEYWORDS}

Ghent system / multi-pillarization / Sweden / trade unions / unemployment insurance

\section{Introduction}

n the so-called 'Ghent system', the state subsidizes voluntarily operated unemployment insurance schemes. The role of the state is limited to regulation, supervision and financial subsidization, while the union-linked unemployment insurance funds are responsible for the administration of the unemployment insurance. The Ghent system is today in operation in Sweden, Denmark, Finland and Iceland. ${ }^{1}$ Sweden is one of the few countries where the Ghent system has survived due to its unions having been successful in making the insurance program attractive for the wider working population during the post-war period (Goul Andersen 2012; Rasmussen \& Pontusson 2018). Unlike the neighboring countries like Denmark and Finland where alternative insurance funds started gaining foothold during the last two decades (Høgedahl \& Kongshøj 2017), the union-linked insurance funds are still dominant insurance providers in Sweden. As of May 2019, there are 26 unemployment insurance funds and all but one of these funds (Alfa-kassa) are linked to specific unions organizing different sectors and professional groups.

Despite retaining voluntary membership in the insurance funds, the Swedish Ghent system has for a long time been characterized by comprehensive coverage and generous

\footnotetext{
${ }^{1}$ You can find this text and its DOI at https://tidsskrift.dk/njwls/index.

${ }^{2}$ Corresponding author: Jayeon Lindellee, Box 23, Lund University, Lund 221 00, Sweden.

E-mail: Jayeon.Lindellee@soch.lu.se.
} 
benefit levels (Rothstein 1992; Scruggs 2007; Sjöberg 2011; Sjöberg et al. 2010). This was possible by collectively pooling the risk of income loss upon unemployment in two ways. First, the state heavily subsidized benefit payments and membership fees so that the generous compensation level as well as the high coverage could be sustained. Second, the contribution fees for everyone insured were kept at uniformly low levels regardless of which insurance funds they belonged to. Additionally, the system also provides basic (flat-rate) benefits for unemployed individuals not belonging to an insurance fund, as long as they fulfil work requirements. These features ensured a wider coverage including workers in sectors and professions facing higher risks of unemployment, which in turn also contributed to high degree of unionization (Clasen \& Viebrock 2008; Høgedal 2014; Lind 2007; Rothstein 1992; Scruggs 2002; van Rie et al. 2011; Western 1997). This is in line with the argument recently put forward by Rasmussen and Pontusson (2018) that the Ghent system has only been successful where the government extensively subsidizes the financing of the insurance funds.

During the last three decades, however, both benefit generosity and recipiency rate of the Swedish public unemployment insurance program have declined. We can identify three reasons for this retrenchment. First, since the economic crisis of the 1990s, both the conservative parties and the Social Democrats implemented benefit cuts, toughened up eligibility criteria and let the gradual erosion of benefit generosity occur by not raising the ceiling (Bandau 2017; Gordon 2017; Rathgeb 2018; Sjöberg 2011). Second, the reforms under the center-right coalition government the Alliance in the mid-2000s with further benefit cuts and toughened eligibility, as well as a retreat of the state's financial contribution, significantly undermined the Ghent system, reducing the coverage of the earnings-related benefits greatly and negatively affecting union density especially among blue-collar workers (Kjellberg 2009, 2011). Finally, changes in the labor market and characteristics among the unemployed may also account for the significant decrease in the benefit recipiency rate. An ever-larger share of unemployed individuals today is poorly protected by the Ghent system, which requires an extended period of work record and insurance fund membership. It is merely one in four among the unemployed who receive the earnings-related benefit from the public unemployment insurance program today (Lindellee 2018, p. 80).

These changes in the public unemployment insurance program are spectacular (see also Gordon 2017) in their scope and scholars have highlighted the impact of weakening Ghent system in Sweden on the union density (Bandau 2017; Høgedahl \& Kongshøj 2017). While the decreasing union density among the blue-collar workers in the aftermath of the reforms during the 2000s is incontestable, I argue that weakening of the Ghent effect has not been uniform across different working populations in Sweden and the Ghent logic has rather been partly strengthened due to the development of complementary benefits for the unemployed, where the unions continue to play a vital role. In order to substantiate this argument, this paper analyzes important parallel changes that have taken place as the retrenchment of the public pillar unfolded: silent institutionalization of complementary benefits for the unemployed.

The unemployed in Sweden today have to relate to several kinds of benefit schemes. Apart from the public unemployment insurance program, different labor market sectors are covered by different complementary benefit arrangements regulated by collective agreements between the main employer and union organizations. These Employment Transitional Agreements (ETAs) have continuously been expanded to cover the entire labor market since their inception in the 1970s. ${ }^{2}$ Besides this occupational welfare

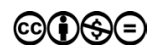


arrangement, there are private complementary income insurance schemes provided by the majority of labor unions for their members, covering half the working population as of 2017 (Lindellee 2018). These are to top-up the benefits from the public unemployment insurance program or prolong the benefit payment period. There are also individual income insurance plans, operating based on risk assessment and premium-setting practices on the individual level. ${ }^{3}$ We may therefore now speak of a multi-pillarization in the provision of unemployment benefits in Sweden. By multi-pillarization, I refer to the changing institutional landscape for unemployment benefit provision, where there is an increase in the importance of different complementary benefits provided by occupational and personal arrangements, or pillars.

The paper proceeds as follows. After a brief account on the analytical focus and data sources reviewed for the study, the main body of the paper provides a detailed account on the distinct path to multi-pillarization of the Swedish unemployment benefit system, with varying consequences for the unions organizing different working populations. The first subsection analyses the retrenchment of the public pillar and the following two subsections analyze the establishment and expansion of the occupational and private pillars respectively. Lastly, I conclude with a discussion about distributive implications of the continued and evolving role of the unions in unemployment benefit provision in Sweden.

\section{Methodology}

The pillar perspective (see Goodin \& Rein 2001, for an extended discussion) and the terminology of multi-pillars have been most widely adopted in pension research, where multi-pillarization has been explicitly and widely embraced by major policy organizations as well as politicians and scholars as a financially sustainable alternative for aging societies (Anderson 2010; Ebbinghaus 2011). Adopting the pillar perspective to the study of unemployment benefit provision system in Sweden is a novel attempt, yet one that which helps us paying attention to the gradual and subterranean institutional changes (cf. Hacker 2004, 2005; Thelen \& Mahoney 2010) that the Swedish unemployment benefit provision system has undergone. While the main institutional features of the public unemployment insurance program have remained intact, the vocabulary of multi-pillar perspective helps us highlight the new functions of the complementary benefit schemes for the unemployed in Sweden.

In this paper, features of the complementary pillars are analyzed by tracing the institutional context from which they emerged and by analyzing the development of different types of complementary benefits. In other words, the analyses are focused on the output level of institutional changes. The overall analytical process may be described as bringing different pieces of information and material into an institutional order that is not necessarily apparent from the outset, through a process of tracking and making sense of a series of events and diverse sources of data. Inspired by the historical institutional approach, this study tries to take into account the institutional origins, path dependency exerted by established institutional legacies and how they over time constrain and shape the actors' room for maneuver as well as interests, preferences and strategies. Some conceptual tools widely used in studies of gradual institutional changes, such as policy drift and layering (Jensen 2014; Hacker 2004, 2005; Thelen \& Mahoney 2010), are used in this paper, as they are heuristically useful in understanding the changes in the Swedish unemployment benefit 
provision system leading to the multi-pillar system of unemployment benefit provision.

The study draws on an extensive set of documents. In analyzing the changes in the public unemployment insurance program, reports and statistics from two state agencies, Swedish Unemployment Insurance Board and Public Employment Service were of great importance. For the analysis of the benefits and support provided via collective agreements between labor market partners, several previous studies have been essential (Bäckström 2006; Jansson et al. 2018; Martinson 2005; Sebardt 2005; Walter 2015). Moreover, some first-hand data were collected by reviewing the websites of the different ETAs and various types of information available on websites belonging to unions and employers' organizations. For the newly developed complementary income insurance schemes for the unemployed, documents from public authorities and agencies, reports from confederations of labor unions (Andrén 2014; Essemyr 2013; Vedin 2014), as well as information from labor unions' websites were reviewed. Additional sources included insurance company websites, insurance plans, leaflets, blogposts, online advertisements, radio, podcast broadcasting, price-comparison websites, related newspaper articles, etc.

\section{Three decades of retrenchment: the public unemployment insurance program}

If the Ghent system as the public pillar of the Swedish unemployment benefit system was at its peak in terms of coverage and benefit generosity at the very beginning of the 1990s, the last three decades have been characterized by several waves of retrenchment reforms. After the deep economic crisis in Sweden in the 1990s, the political and economic contexts within which the Ghent system could operate successfully as the public pillar of unemployment benefit system came under the strain of fiscal concerns. Since then, the benefit level and eligibility criteria have continuously developed towards public unemployment insurance benefits that are less generous and more difficult to qualify for. The long-term incremental change leading to the continuous decline in benefit generosity has weakened the public pillar's function as providing earnings-related unemployment benefits. Although the gross replacement rate of earnings-related unemployment insurance benefits remained rather stable, the lack of benefit indexation and several extended periods of non-decision by the government in adjusting the benefit ceiling effectively undermined the generosity of the benefits, turning the earnings-related benefits into de facto flat-rate benefits for the majority of wage earners.

Figure 1 is an attempt to grasp the effects of this 'politics of indexation' (Weaver 1988) over time. The dotted line on the top of the graph illustrates the gross replacement rate, which has been stable at $80 \%$ since 1997 . The straight line in the middle illustrates the maximum benefit amount as a share of the average wage for each year, showing a consistent decrease, with the exception of 2002 and 2015 when the benefit ceiling was raised. In 1994, the unemployment insurance benefits could compensate for $80 \%$ of previous earnings of an average wage worker. In contrast, an unemployed person earning the average wage in 2014 who fulfilled the eligibility criteria for the earnings-related benefits could at most receive $48 \%$ of his/her previous income from the public unemployment insurance program. The basic flat-rate benefits, which are paid out for those who fulfil the work requirements but not the membership requirements, has steadily decreased from $32 \%$ of the average wage in 2002 , when the last raise took place, to $21 \%$ of the average

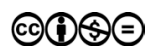


Figure I Changes in the formal, maximum and minimum replacement rates in Swedish unemployment insurance benefit, $199 \mid-2016$.

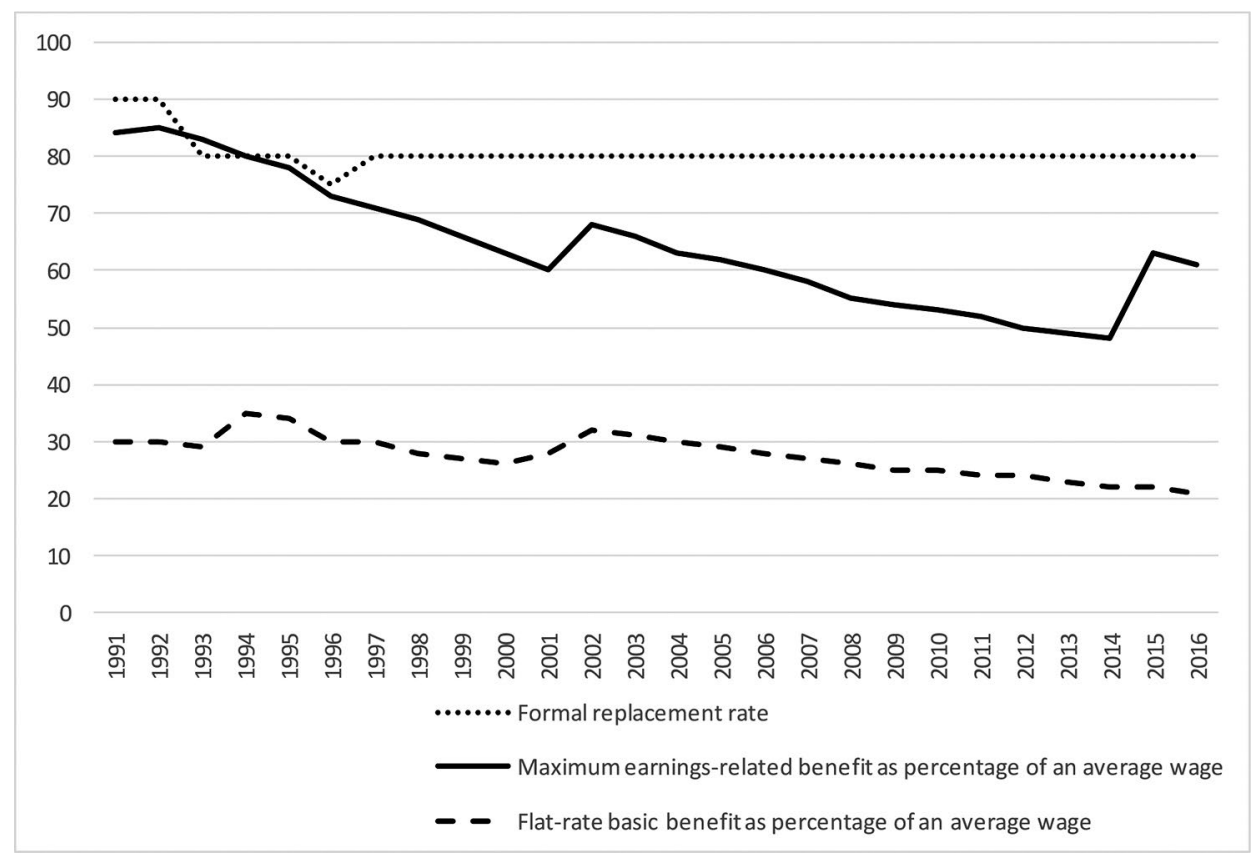

Source: Benefit level from the Swedish Unemployment Insurance Board (IAF) and average wage for each year from Statistics Sweden (SCB).

Note: Data on daily benefit payments from IAF were used for calculating monthly benefit level, which was then divided by the average wage of each year in order to estimate the replacement rate as a percentage of the average wage.

wage in 2016 (dashed line in the bottom). Even with the recent rise of the benefit ceiling in 2015, the average wages among private sector blue-collar workers, for both males and females, were already above the benefit ceiling in 2017 (SCB 2017). This means that the majority of wage-earners are unable to secure the formal replacement rate of $80 \%$ of previous income by receiving unemployment insurance benefits.

In other words, the effective income replacement rate for the unemployed whose previous income is higher than the benefit ceiling has deteriorated almost constantly with the exception of minor, temporary increases when the ceiling was raised in 2002 and 2015. As pointed out by Green-Pedersen et al. (2012), not indexing or changing indexation rules for unemployment benefits is a less-noticed but popular way of retrenchment, found in diverse institutional contexts across different welfare-state regimes and political colors of the governments involved. Even though the Social Democratic government raised the ceiling by $33 \%$ in 2015 , there was little discussion concerning reintroducing indexation for the benefit ceiling (Promemoria 2014). This implies that as the years pass, the relative level of maximum benefits will gradually and continuously decrease again.

The changes in the generosity of the public pillar in terms of decreasing the effective income replacement level and stricter eligibility have taken place more or less consistently 
since the 1990s, regardless of the ideological orientation of the governments in power. The Social Democratic governments did not completely reverse the benefit cuts made by a right-wing coalition during the 1990s (Gordon 2017, p. 6), which allowed for the continued erosion of the earnings-relatedness of unemployment insurance benefits. What has significantly weakened the Ghent system further in the recent decade are the changes introduced by the center-right Alliance government in 2006, increasing as well as differentiating the unemployment insurance fee levels (Prop., 2006/07:15). When the Alliance government simultaneously reduced the state subsidies in two ways (i.e., by raising the insurance funds' fees to the state and abolishing the tax deduction for the insurance fund membership fees (Prop. 2006/07:15)), the coverage of the earnings-related unemployment insurance benefits, especially among workers exhibiting relatively higher risks of unemployment, dropped to an unprecedented extent (Kjellberg 2009, 2010/2014).

Another important aspect of this change, however, was the fact that the increased financial burden on the unemployment insurance funds was unequally distributed due to the differentiation of membership fees across insurance funds, which aimed to tighten the relationship between the risk of unemployment in different sectors and the membership fees for the unemployment insurance funds. By abolishing the redistribution mechanism of resources among the insurance funds through the 'leveling fee'4 (Prop. 2006/07:15), the effect of the tighter link between insurance membership fees and the sectoral unemployment rate achieved by the unemployment fee was further strengthened (IAF 2013; Kjellberg 2011, p. 74). As a result, the difference in membership fees between different unemployment insurance funds increased from a maximum of SEK 36 in 2006 to SEK 359 in $2013 .{ }^{5}$ These changes during the last decade reveal the importance of the state's financial commitment for the Ghent system most starkly. It became thus evident during the aftermath of the reforms that the Ghent system is highly vulnerable without a substantial financial commitment from the state, as those who could not afford the membership fees both left and refrained from signing up for the insurance funds.

Despite this vulnerability of the Ghent system, the voluntary membership to the union-linked insurance funds has remained a core institutional feature and it does not seem as if this trait will be easily abandoned. This is because the institutional origin of the Ghent system during its formative years and its particular impact on union density over time has led to deep-seated interests and preferences among the unions to be continuously involved in the provision of unemployment protection. However, this institutional inertia has been accompanied by a range of significant changes in other aspects of the Ghent system, beginning in the 1990s. With the arrival of new sets of goals governing the economic and labor market policies in the aftermath of the economic crisis, together with the weakened corporative policy-making practice, the unions became increasingly less successful in combating retrenchment of the public unemployment insurance program. Symptomatic of this critical period is that the unions and the Social Democratic Party started exhibiting disagreement in relation to benefit generosity, eligibility level, the goal of the unemployment insurance, etc. (Anderson 1998; Timonen 2003).

Therefore, although the core institutional architecture of the Ghent system remained resilient, this does not mean that this institutional continuity guarantees sustained risk protection outcomes regardless of shifting political ideologies governing the public unemployment insurance program or constantly changing labor market structures. This subsequently opened up for other forms of institutional change, such as drift and layering as discussed in the literature on gradual institutional change (Hacker 2004, 2005;

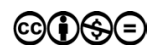


Thelen \& Mahoney 2010). Policy drift indicates a process where the outcomes of quite stable policies may significantly change due to shifts in the social context of policies. The policy drift when it comes to the benefit ceiling of the unemployment insurance benefits has meant that earnings-related benefits have in fact been converted into basic flat-rate benefits for many workers, leading to a social protection gap (Bonoli et al. 2000, p. 46) with an increasing share of workers unable to get full compensation for their lost income upon unemployment. This social protection gap has to some extent been filled by the maturing ETAs and newly established complementary income insurance schemes guaranteeing full income compensation above the ceiling in the public unemployment insurance program, which we now turn to.

\section{Silent institutionalization of occupational pillar - Employment Transition Agreements}

Swedish occupational welfare provision is characterized by far-reaching, relatively uniform and centralized arrangements providing additional social protection for workers on top of the statutory programs (Greve 2018; Jansson et al. 2016; Sebardt 2005). Through collective negotiation and administration, a handful of actors provide complementary benefits for wage earners in the case of old age, workplace accidents, sickness, unemployment, parental leave and so on. The main function of the benefits provided via collective agreements is to complement the statutory benefits provided by social insurance schemes, as all social insurance schemes have maximum ceilings in terms of the level of earnings-related benefits one may receive.

The occupational pillar in unemployment benefit provision is no exception. The Swedish labor market partners have autonomously developed a unique set of collective agreements over the last fifty years in order to manage redundancy. As early as in the 1970s, the union confederations and employers' organizations established cross-industrial agreements, which may generally be referred to as ETAs. As of 2012, when over a million local and regional government employees became covered by the Transition Fund (Omställningsfonden), one can say that all major labor market sectors are covered by ETAs. Internationally, it is rather uncommon to find such comprehensive coverage of occupational welfare in the area of unemployment protection (Jansson et al. 2016; Walter 2015) and this may be understood in light of the strong Swedish tradition of bilateral self-regulation and conflict management between employers and workers via collective agreements (Elvander 2002).

The ETAs cover most workers in the Swedish labor market as of 2017 (See Table 1). Within the framework of these agreements, there are nonprofit foundations and councils, owned and managed by actors from both sides of the labor market. The common goal of the ETAs is to support and facilitate a successful transition of the unemployed to new employment (or full-time education) both via economic compensation complementing the public unemployment benefits and via employment services complementing the support provided by the Public Employment Service. The following is a short description of the economic compensation provided by the main ETAs.

For the state sector, the Job Security Foundation (Trygghetsstiftelsen) founded in 1990 covers about 250,000 state employees. For those covered by this agreement, there are complementary benefits topping up the public unemployment benefits over the ceiling. In order to receive these benefit, permanent employment prior to unemployment is 
Table I Main Employment Transitional Agreements (ETAs) in Sweden, 2017

\begin{tabular}{|c|c|c|c|c|c|}
\hline Sectors & ETAs & $\begin{array}{l}\text { Year of } \\
\text { introduction }\end{array}$ & $\begin{array}{l}\text { Coverage } \\
\text { (persons) }\end{array}$ & $\begin{array}{l}\text { Benefit } \\
\text { form }\end{array}$ & Eligibility criteria \\
\hline $\begin{array}{l}\text { State } \\
\text { employees }\end{array}$ & $\begin{array}{l}\text { Job Security } \\
\text { Foundation }\end{array}$ & $1990 / 2014$ & 250,000 & $\begin{array}{l}\text { Complementary } \\
\text { insurance } \\
\text { benefit }\end{array}$ & $\begin{array}{l}\text { Permanent employment } \\
\text { and minimum length of } \\
\text { employment }\end{array}$ \\
\hline $\begin{array}{l}\text { Local and } \\
\text { regional } \\
\text { government } \\
\text { employees }\end{array}$ & $\begin{array}{l}\text { The } \\
\text { Transition } \\
\text { Fund }\end{array}$ & 2012 & $1,100,000$ & $\begin{array}{l}\text { Complementary } \\
\text { insurance } \\
\text { benefit }\end{array}$ & $\begin{array}{l}\text { Permanent employment } \\
\text { and minimum length of } \\
\text { employment }\end{array}$ \\
\hline $\begin{array}{l}\text { Private sector } \\
\text { blue-collar } \\
\text { workers }\end{array}$ & $\begin{array}{l}\text { Employment } \\
\text { Transition } \\
\text { Fund }\end{array}$ & 2004 & 900,000 & $\begin{array}{l}\text { Lump-sum } \\
\text { benefit }\end{array}$ & $\begin{array}{l}\text { Age and minimum } \\
\text { length of employment }\end{array}$ \\
\hline $\begin{array}{l}\text { Private sector } \\
\text { white-collar } \\
\text { workers }\end{array}$ & $\begin{array}{l}\text { Employment } \\
\text { Security } \\
\text { Council }\end{array}$ & $1974 / 1998$ & 850,000 & $\begin{array}{l}\text { Complementary } \\
\text { insurance } \\
\text { benefit }\end{array}$ & $\begin{array}{l}\text { Age and minimum } \\
\text { length of employment }\end{array}$ \\
\hline
\end{tabular}

Source: Websites of each Employment Transitional Agreement.

required for full compensation. Fewer days of payment are offered for those with temporary employment, depending on length of employment (new element since 2014). For employees working at local and regional government bodies, there is the Transition Fund (Omställningsfonden, KOM-KL). It came about most recently, in 2012, but is nonetheless the largest in terms of coverage, covering 1.1 million employees. For those covered by this agreement, there are complementary benefits topping up the public unemployment benefits over the ceiling, up to $80 \%$ of the previous salary for the first 200 days and then $70 \%$ for the following 100 days. These benefits require permanent employment for the last four out of five years of consecutive employment. For private sector blue-collar workers, the Employment Transition Fund (Trygghetsfonden, TSL) was founded in 2004 and it covers 900,000 employees. A lump sum severance payment AGB (Avgångsbidrag) is provided for those covered by this agreement. Basic eligibility criteria for these benefits include being above the age of 40 and having been employed for at least 50 months during the last five years before unemployment. For private sector white-collar workers, the Employment Security Council (Trygghetsradet, TRR) was founded in 1974 and covers 850,000 employees. For those covered by this agreement, complementary unemployment benefits topping up the public unemployment benefits over the ceiling is provided, up to $70 \%$ of the previous salary for a six-month period and $50 \%$ thereafter. One has to be over the age of 40 to receive this compensation, and the benefit level and period vary depending on age and previous salary. Apart from these four major ETAs, there are seven additional similar arrangements covering specific labor market sectors, but these are smaller in scope in terms of coverage. These include the culture and non-profit sector, real estate, banking and other financial services, the cooperative sector and the church, all founded between the early 1970s and the 2000s (Walter 2015, p. 25).

Even though these different ETAs developed independently of each other without any formal coordination by major actors or the state (Jansson et al. 2018, p. 61; Walter 2015, pp. 126-127), the governance arrangements as well as the range of benefits and 
services provided are very similar. Some differences, however, may be found in terms of more detailed eligibility criteria and level of benefits provided. The expansion of the Employment Transition Agreements has been possible due to the significant strength and organizational capacities of the labor market partners with their centralized umbrella organizations that have been active in the provision of a range of occupational benefits for a long time (Jansson et al. 2018; Trampusch 2013). This layering of occupational schemes covering most workers in Sweden certainly demonstrates a potential of comprehensive risk protection via bilateral agreements between the labor market partners compared to, for instance, firm-level occupational welfare provision, which may result in a much more varying degree of protection. Nevertheless, the limits of solidarity appear to be clear.

At a closer look, the generosity and eligibility criteria in relation to the benefits provided by the ETAs differ across different labor market sectors, as pointed out above. As in the Swedish occupational pension provision, the main cleavage can be found between the agreement covering private sector blue-collar workers and the other major schemes, the former being a latecomer as well as less comprehensive and generous than the schemes covering the rest of the working population in the public sector and private white-collar workers (compare, for instance, with pension provision in Jansson et al. 2018).

This silent institutionalization of the ETAs developed into a unique, unprecedented occupational pillar. This is in line with the understanding of industrial relations as a source of egalitarian welfare reforms in the face of welfare state retrenchment (Trampusch 2007). This pillar reflects the strong organizational resources and governance capacity of the labor market partners in Sweden, reinforcing the importance of the Swedish model and in turn legitimizing the importance of a high organizational level for both employers and workers. Whereas the corporatist institutions and norms in policymaking have weakened significantly (Lindvall \& Sebring 2005; Rothstein \& Bergström 1999), the application of collective agreements as the principal way of governing industrial relations and providing occupational welfare to workers seems to remain strong in Sweden.

\section{Emergence and expansion of private pillar - Complementary income insurance schemes}

While the occupational pillar consisting of the Employment Transition Agreements has evolved slowly since the 1970 s, the complementary income insurance schemes have expanded rather swiftly over the last fifteen years. As the level of earnings-related benefits from the public unemployment insurance program has continued to deteriorate since the 1990s, a large share of workers has become unable to fully insure against income loss upon unemployment merely by becoming a member of an unemployment insurance fund. Therefore, complementary income insurance schemes started to emerge providing full compensation of the lost income even above the benefit ceiling in the public unemployment insurance program. However, full compensation is here limited up to $80 \%$ of the previous income for the first 200 days and $70 \%$ for the rest of the period, which corresponds to the levels regulated by the law on unemployment insurance (SFS 1997:238, $26 \mathbb{S}$ ). 
The development of this third pillar is shaping the new terrain of the Swedish unemployment benefit provision system today, as it reinforces the Ghent logic due to its union-led development at the same time as it introduces a more consumerist understanding of the income protection system for the unemployed. Table 2 provides some key features of the complementary income insurance schemes provided by the unions as well as the coverage figures of this third pillar for different union collectives as of 2017. For an extensive overview of all existing complementary income insurance schemes provided by unions as of 2017, see Lindellee (2018).

Table 2 Key features and coverage of complementary income insurance schemes provided by unions in Sweden, 2017

\begin{tabular}{|c|c|c|c|c|}
\hline $\begin{array}{l}\text { Union } \\
\text { collectives }\end{array}$ & $\begin{array}{l}\text { Year of } \\
\text { introduction }\end{array}$ & $\begin{array}{l}\text { Qualification } \\
\text { period }\end{array}$ & $\begin{array}{l}\text { Benefits included } \\
\text { in membership }\end{array}$ & $\begin{array}{l}\text { Coverage* } \\
\text { (among union } \\
\text { members belonging } \\
\text { to active workforce) }\end{array}$ \\
\hline SACO & $2003-2016$ & $12-18$ months & $\begin{array}{l}\text { 120-150 days, ceilings*** } \\
\text { between SEK 50,000 and } \\
100,000\end{array}$ & $97 \%$ \\
\hline TCO & $2005-2010$ & 12 months & $\begin{array}{l}\text { 100-200 days, ceilings } \\
\text { between SEK 60,000 and } \\
100,000\end{array}$ & $99 \%$ \\
\hline LO & $2007-2011$ & 12 months & $\begin{array}{l}\text { I00-200 days, generally no } \\
\text { ceiling, except one union } \\
\text { SEK } 35,000\end{array}$ & $67 \%$ \\
\hline
\end{tabular}

Source: Lindellee (2018, Chapter 5)

Note: *The coverage is here calculated in relation to union members belonging to the active workforce, excluding, for instance, retirees and students. As complementary income insurance scheme is not available for this population, the precise coverage of the schemes is calculated only in relation to the members belonging to the active workforce. The figures for 2017 represent from my own calculation of available information from all unions providing complementary income insurance benefits as well as communications with the secretariats of SACO,TCO and LO. In 2017,5.3 million individuals were in the active labor force according to Labor Force Surveys by Statistics Sweden.

*** Benefit ceiling for an insurable monthly income.

The major expansion of the complementary income insurance market in terms of coverage has been driven by initiatives of labor unions in the form of group insurance schemes, which is why the contractual relationship between insurance companies and individual workers to a great extent is mediated by unions. Starting in the early 2000s, unions organizing professionals with university degrees (affiliated with $\mathrm{SACO}^{6}$ ), soon followed by unions for white-collar workers $\left(\mathrm{TCO}^{7}\right)$, started introducing group-based income insurance for their members, either in cooperation with insurance companies or by launching their own mutual insurance companies. The blue-collar unions $\left(\mathrm{LO}^{8}\right)$ caught up with this trend starting in the late 2000s. Most of them have their complementary income insurance scheme included in their membership package, which means that individual members do not have to sign a separate contract with insurance providers once they become union members. Many, but not all, additionally provide voluntary schemes individual members may choose to purchase, which guarantees complementary 
benefit payments for longer periods or a higher level of income for which to receive compensation.

In 2004, merely eight unions had premiums for their complementary income insurance included in their membership fees. The figure increased to 32 already in 2009 (Lindquist \& Wadensjö 2011, p. 43) and to 35 as of 2017. In 2017 an estimation of 2.4 million people in Sweden were covered by union membership-based complementary income insurance schemes, corresponding to roughly half the entire population in the active labor force (Lindellee 2018). The rapid expansion of this third pillar of the unemployment benefit provision system has to some extent taken place below the radar of the wider public, which is why there has not been much public debate on this extra layer of the Swedish unemployment protection system (Andrén 2015, pp. 58-59). There is no government intervention in relation to these schemes other than that the law unemployment insurance benefits regulates the maximum level of income replacement rate (SFS 1997:238, 26\$). Moreover, the complementary income insurance benefits are not subject to taxation (SOU 2015:21, p. 787).

Despite that individual unions have introduced complementary income insurance schemes at different time points and in collaboration with different insurance companies, the similarities among the schemes are striking. Some common features include that the qualification period that is minimum 12 months and that all of the complementary income insurance schemes provided by the unions require that beneficiaries receive the maximum level of the earnings-related benefits from the public unemployment insurance program. Yet, there is certainly some variation across different unions. For instance, when it comes to benefit period, this varies between 100 to 200 days. Members of the Swedish Union of Journalists (Journalistförbundet) may, for instance, receive the complementary income insurance benefits up to 100 days, whereas members of the Swedish Association of Health Professionals (Vårdförbundet) may receive the benefits up to 200 days. Additionally, many of them provide supplementary insurance schemes for an additional premium, which guarantees a longer benefit period. For instance, by being a member of the Union of Civil Servants (Fackförbundet ST), one may receive the complementary income insurance benefits for the first 150 days, with the possibility of signing up for a supplementary insurance scheme guaranteeing 150 additional days for an extra monthly premium. This means that regardless of whether or not one's previous income exceeds the ceiling in the public unemployment insurance, one may receive full income compensation ( $80 \%$ of previous income). The level of maximum income that may be compensated for varies among the unions as well. The maximum level of insured income varies between SEK 35,000 and SEK 100,000 per month. ${ }^{9}$ Similar to the supplementary schemes guaranteeing a longer benefit period, there are supplementary schemes guaranteeing a higher level of maximum monthly income to be compensated for, for example in the case of the Union of Insurance Employees (FTF). For a monthly premium of SEK 82, their members can sign up for a supplementary scheme guaranteeing a higher level of income to be compensated - up to SEK 100,000 - compared to their complementary income insurance scheme included in the union membership, which offers coverage up to a monthly income of SEK 80,000.

Many unions today actively promote their complementary income insurance, and it is often listed first among the benefits of being a member. Unionen, the largest white-collar union in Sweden (640,000 members) in the private sector that has greatly expanded its membership base during the last ten years, stands out in its marketing 
strategy in membership recruitment practices involving advertising its complementary income insurance. The following text is from an advertisement in the form of a poster attached to a local bus in the city of Malmö:

You have insured your car properly. How about your income? Become a member of Unionen and our income insurance is included. With that you get up to $80 \%$ of your income for 150 days between jobs. If you are only a member of a public unemployment insurance fund, then you get a maximum of around SEK 11,000 per month after tax.

Similar to the TCO unions, virtually all SACO unions have introduced complementary income insurance schemes as part of their membership package, starting as early as in 2003. Only the unions organizing military officers, reserve officers and maritime officers do not provide income insurance as a part of membership. Considering that the unemployment rate among workers with university degrees is generally low, one could question the extent of the establishment of complementary income insurance among the SACO members. On the other hand, as the average income level among highly educated workers is higher, the continuously declining effective income replacement rate in the public unemployment insurance program does provide great incentives for the SACO unions to offer their members the possibility of additional income protection. As an illustration, the following text from the SACO website appeals to their members with higher managerial positions concerning their potential need for complementary income insurance.

Do you believe that you get $80 \%$ of your salary from the public unemployment insurance if you become unemployed? If so, you're probably wrong. The majority of university graduates get much less than that. Even if the ceiling in the public unemployment insurance were to be raised, there are many graduates who don't get $80 \%$ of their salary when they become unemployed [...] The higher your income, the more you have to lose. Especially for those of our members who are managers with a high income.

Being a latecomer in the provision of complementary income insurance, it is among LO member unions where we find the lowest coverage of this third pillar at around $67 \%$ (Lindellee 2018). Similar to the occupational pillar, the development of this private pillar indicates that additional collective risk protection is the most developed for those facing the least risk (i.e., unions for white-collar and professional workers with higher educational backgrounds). While some of the TCO and SACO unions saw the opportunity to boost their membership recruitment through this new entitlement based exclusively on union membership, ${ }^{10}$ some others, especially among the blue-collar unions, considered this development undesirable, as they ideologically opposed the idea of state-subsidized public unemployment benefits turning into a basic protection at a low level while leaving room for complementary benefits through private initiatives (Davidsson 2014).

In contrast to TCO and SACO unions, only one union (The Commercial Employees' Union (Handels)) provides the option of supplementary insurance guaranteeing a longer benefit period for an extra premium. Handels is also the only LO union whose complementary income insurance has a benefit ceiling for an insurable monthly income at SEK 35,000 . The others have no ceiling and this is presumably because the average wage level among the potential unemployed members is sufficiently low and hence there is no need for setting an explicit ceiling. The views of some LO unions with regard to this 
new pillar of complementary income insurance are rather ambivalent up until today. They took the role of complementary benefit provision reluctantly, as many of the LO unions initially ideologically opposed introducing such complementary income insurance schemes as previously mentioned. They argue that the public unemployment insurance should improve in terms of coverage and income compensation to the extent that complementary benefits would not be needed at all (Gunnarsson 2010; Junttila 2006).

The major role of the unions in creating the third pillar of Swedish unemployment benefit provision reflects how the unions' strategy in the governance of the unemployment benefit system has turned into a more complex and multi-faceted one. On the one hand, they continuously defend the Ghent system and push for more generous benefit provision and better coverage. With the Social Democratic government restored in office in 2014 after eight years of the center-right Alliance coalition government, there has certainly been a series of changes raising the benefit level and increasing access to benefits (Promemoria 2014; Prop. 2014/15:99), which the unions have been the strong proponents of. On the other hand, the development of union-mediated complementary income insurance schemes covering half the working population today reflects that the unions have taken an alternative route to retain the legitimacy of the Ghent system.

One could discuss if the emergence and establishment of the third pillar can be understood as 'layering', in that a new institutional element is grafted onto the old ones (Thelen \& Mahoney 2010, p. 17). In this scenario, Hacker (2004)'s conceptualization of a collective actor facing few veto players, yet a high barrier for influencing a given policy, can aptly describe the position of unions that increasingly found themselves unsuccessful to exert influence over the first pillar. However, this interpretation would require further analysis of the motives and ideas held by the unions as well as the decision-making process leading up to the introduction of the complementary income insurance schemes by the unions, for instance by means of more archival work and interview studies.

\section{Conclusion: Reinforced union involvement and its distributive implications}

The Ghent system and the Ghent effect arguably functioned as institutional resources for the trade union mobilization during the 20th century in Swedish welfare state. The recent development concerning the establishment of the complementary benefits for the unemployed highlighted in this paper illustrates the resilience of that institutional basis, in terms of the unions' continued role in shaping the path to multi-pillarized unemployment benefit provision system.

The Swedish labor unions have certainly kept their seat at the negotiation table for the various corporative structures for the provision of unemployment benefits in Sweden. They are practically involved in all three pillars: with their insurance funds in the case of the public pillar, with their bilateral collective agreements with employers' organizations in the case of the occupational pillar and, lastly, with their membershipbased complementary income insurance schemes for the private pillar. The Swedish unions' interest and strategies concerning the governance of the unemployment benefit provision system have thus evolved in tandem with shifting economic and labor market policy contexts. While they gradually lost influence in shaping the public unemployment 
insurance scheme, they at the same time reinvented their role as a direct provider of the complementary unemployment benefits, rendering the weakening public unemployment insurance program more resilient to reform pressures.

In the place of conclusion, I focus on teasing out the distributive implications of this development. The unions' involvement in the governance of unemployment benefit provision today occurs against the background of different union organization trajectories as well as changing power balances between the union collectives, where the dominant power of the blue-collar unions has weakened as the white-collar unions have gained more influence and increased their membership base (Ibsen \& Thelen 2017, p. 414). Accordingly, the winner of this development seems to be the unions organizing whitecollar workers and professionals with university degrees, as they have achieved a comprehensive coverage of the complementary income insurance schemes in their respective union collectives. Allegedly, this has also contributed positively to membership development as well. The blue-collar unions, however, have only been reluctant followers in this development and their membership loss since the reforms under the Alliance government has only partially recovered thus far.

The continued yet changing union involvement in the Swedish unemployment benefit provision system thus has double implications from a distributive point of view. On the one hand, the active role of unions as a collective intermediary between the insurance market and individuals means that the extent of risk privatization is moderated. On the other hand, the pronounced class-segregated aspect in the union organization in Sweden (Kjellberg 2017, pp. 248-249) means that the union-led development of the complementary pillars for unemployment benefit provision reinforces the differences in risk protection between different occupational groups and sectors, which was an apparent problem already from the initial emergence of voluntary unemployment insurance funds in the late 1890s. The fact that union density decreased greatly among the LO organizations while that among the SACO and TCO unions did not during the last decade (Kjellberg 2018) also speaks in favor of a future development where the dualization tendency of the unemployment benefit provision system may be aggravated.

One could interpret the development of the third pillar as a reflection of weakening union influence in shaping the public unemployment insurance program, at the same time as it may be seen as a renewed way of exploiting the selective advantages of union membership starting with the introduction of group-based complementary income insurance schemes; in other words, effectively capitalizing on the eroded benefit generosity in the public pillar. However, this selective advantage turned out to be more beneficial for some union collectives than others, and it remains to be seen in which ways this newly institutionalized benefit scheme exerts its own effects on the interest, preference and strategy of the unions when it comes to their involvement in the governance of the Swedish unemployment benefit provision system. What is certain, however, with regard to the extensive institutionalization of the third pillar consisting mainly of unionmediated group-based complementary income insurance schemes, is that which union one belongs to matters for what level of unemployment benefit one becomes entitled to. The development of the Swedish unemployment benefit provision system thus can be aptly described as a gradual institutional change process where previously established preferences of key collective actors continue to exert its effects. Yet, their main strategies have adapted to the changing political conditions and the distributive consequences of such adaptions do not stay the same. 
Considering the theoretically claimed and empirically established role of the Ghent effect on unionization in the countries such as Sweden, Finland and Denmark, comparative studies on the changing trajectories of the Ghent systems in these contexts would be a promising research task to understand how the institutional embeddedness of the Ghent system is evolving in the face of changing unionization trends (Høgedahl \& Kongshøj 2017).

\section{References}

Anderson, K. (2010). Promoting the multi-pillar model? the EU and the development of funded pension schemes. In: Ross $M$ and Borgmann-Prebil Y (eds) Promoting Solidarity in the European Union, Oxford Scholarship Online. doi: 10.1093/acprof:oso/9780199583188.001.0001.

Anderson, K. (1998). The welfare state in the global economy: The politics of social insurance retrenchment in Sweden 1990-1998, Washington, DC: University of Washington.

Andrén, T. (2014). Inkomstförsäkringar och tid i arbetslöshet - Leder kollektiva inkomstförsäkringar till högre arbetslöshet bland akademiker?[Income insurance schemes and time in unemployment - Do income insurance schemes lead to higher unemployment among the academics?], Sveriges akademikers centralorganisation (SACO).

Andrén, T. (2015). Inkomstförsäkringars effekt på arbetslöshet och matchning. [Income insurance schemes' effect on unemployment and matching.] Arbetsmarknad \& Arbetsliv 21(1): 54-71.

Bandau, F. (2017). Storming Labour's Last Strongholds: Union Decline and the Partisan Politics of the Ghent System. Working paper, University of Bamberg.

Bonoli, G., George, V. \& Taylor-Gooby, P. (2000). New Directions in European Welfare Policy: From Decommodification to Recommodification. In: Bonoli, G., George, V. \& Taylor-Gooby, P. (eds) European Welfare Futures: Towards a Theory of Retrenchment, Cambridge: Policy Press.

Bromander, K. (2017). TCO närmar sig LO:s medlemstal. [TCO getting closer to LO's number of members.] Arbetsvärlden, 7 February.

Bäckström, H. (2006). Omställningssystemets agenter och försäkringar på den svenska arbetsmarknaden. Bemanningsföretag, försäkringsbolag, myndigheter och trygghetsråd $i$ helig allians? [Agents of employment transition and insurance schemes in the Swedish labor market. Manpower companies, insurance companies, state agencies and Employment Transition Council in a holey alliance?] Arbetslivsrapport 2006:4, Stockholm: Arbetslivsinstitutet.

Clasen, J. \& Viebrock, E. (2008). Voluntary unemployment insurance and trade union membership: Investigating the connections in Denmark and Sweden, Journal of Social Policy 37(3): 433-451. doi: https://doi.org/10.1017/S0047279408001980.

Davidsson, J.B. (2014). The Limits of Solidarity. Unions, Redistribution and the Rise of Private Unemployment Insurance in Sweden, Presentation at the Max Planck Institute für Gesellschaftsforschung, Cologne, 24-25 July 2014.

Ebbinghaus, B. (2011). The Varieties of Pension Governance: Pension Privatization in Europe, Oxford: Oxford University Press. doi: 10.1093/acprof:oso/9780199586028.001.0001.

Elvander, N. (2002). The labour market regimes in the Nordic countries: A comparative analysis, Scandinavian Political Studies 25(2): 117-137. doi: https://doi.org/10.1111/14679477.00066.

Essemyr, M. (2013). Arbetslöshetstid och inkomstförsäkringar. Driver fackens inkomstförsäkringar upp arbetslösheten? [Length of unemployment and income insurance schemes. Do 
unions' income insurance schemes drive up unemployment?] TCO granskar. nr. 1, Stockholm: Tjänstemännens centralorganisation (TCO).

Goodin, R.E. \& Rein, M. (2001). Regimes on pillars: Alternative welfare state logics and dynamics, Public Administration 79(4): 796-801. doi: https://doi.org/10.1111/14679299.00280 .

Goul Andersen, J. (2012). Universalization and De-universalization of Unemployment Protection in Denmark and Sweden. In: Anttonen, A., Häikiö, L. \& Stefánsson, K. (ed) Welfare State, Universalism and Diversity, Cheltenham: Edward Elgar.

Gordon, J.C. (2017). The perils of vanguardism: Explaining radical cuts to unemployment insurance in Sweden, Socio-Economic Review 17(4): 947-968. doi: https://doi.org/10.1093/ ser/mwx046.

Green-Pedersen, C., Christiansen, F.J., Euchner, E.M., Jensen, C. \& Turnpenny, J. (2012). Dismantling by Default? The Indexation of Social Benefits in Four Countries: Non-decisions and invisible cutbacks? In: Bauer, M.W., Jordan, A., Green-Pedersen, C. \& Héritier, A. (eds) Dismantling Public Policy: Preferences, Strategies, and Effects, New York: Oxford University Press. doi: 10.1093/acprof:oso/9780199656646.001.0001.

Greve, B. (2018). At the heart of the Nordic occupational welfare model: Occupational welfare trajectories in Sweden and Denmark, Social Policy \& Administration 52(2): 508-518. doi: https://doi.org/10.1111/spol.12380.

Gunnarsson, H. (2010). Försäkringen ger arbetslösa LO-medlemmar miljoner. [The insurance provides LO's unemployed members millions.] Kommunal arbetaren, 30 September.

Hacker, J.S. (2004). Privatizing risk without privatizing the welfare state: The hidden politics of social policy retrenchment in the United States, American Political Science Review 98(2): 243-260. doi: https://doi.org/10.1017/S0003055404001121.

Hacker, J.S. (2005). Policy drift: The Hidden Politics of US Welfare State Retrenchment. In: Thelen, K. \& Streeck, W. (eds) Beyond Continuity, Institutional Change in Advanced Political Economics, New York: Oxford University Press.

Høgedahl, L. \& Kongshøj, K. (2017). New trajectories of unionization in the Nordic Ghent countries: Changing labour market and welfare institutions, European Journal of Industrial Relations 23(4): 365-380. doi: https://doi.org/10.1177/0959680116687666.

Høgedal, L. (2014). The Ghent effect for whom? mapping the variations of the Ghent effect across different trade unions in Denmark, Industrial Relations Journal 45(6): 469-485. doi: https://doi.org/10.1111/irj.12072.

IAF (2013). Finansieringen av arbetslöshetsförsäkringen. Uppfölining initierad av IAF. [The financing of unemployment insurance system. A follow-up initiated by IAF.] 2013:2, Katrineholm: Inspektionen för arbetsläshetsförsäkringen (IAF).

Ibsen, C.L. \& Thelen, K. (2017). Diverging solidarity. Labour strategies in the new knowledge economy, World Politics 69(3): 409-447. doi: 10.1017/S0043887117000077.

Jansson, O., Ottosson, J., Murhem, S. \& Magnusson, L. (2016). Unemployment and Pensions Protection in Europe: the Changing Role of Social Partners, PROWELFARE country report: Sweden. OSE Paper Series. Research Paper. No. 26, Brussels: European Social Observatory.

Jansson, O., Ottosson, J., Murhem, S. \& Magnusson, L. (2018). Sweden: supplementary occupational welfare with near universal coverage. In: Natali, D., Pavolini, E. \& Vanhercke, B. (eds) Occupational Welfare in Europe: Risks, opportunities and social partner involvement, Brussels: ETUI.

Junttila, C.J. (2006). Kommunal utreder inkomstförsäkring. [Kommunal investigates income insurance schemes] Kommunal arbetaren, 13 December.

Kjellberg, A. (2009). The Swedish Ghent system and trade unions under pressure. Transfer 15(3-4): 481-504. doi: https://doi.org/10.1177/10242589090150031601.

Kjellberg, A. (2010/2014). Vilka "hoppade av" a-kassan eller avstod frä att gå med? En studie av a-kassornas medlemsras [Who "quit" the public unemployment insurance funds 
or abstained from becoming members? A study of unemployment insurance funds' membership decline], Studies in Social Policy, Industrial Relations, Working Life and Mobility. Research Reports; Vol. 2014:2, Lund: Department of Sociology, Lund University.

Kjellberg, A. (2011). The Decline in Swedish Union Density since 2007, Nordic Journal of Working Life Studies 1(1): 63-97. doi: https://doi.org/10.19154/njwls.v1i1.2336.

Kjellberg, A. (2017). Fack, arbetsgivare och industrial relations. [Unions, employers and industrial relations.] In: Bengtsson $\mathrm{M}$ and Berglund $\mathrm{T}$ (eds) Arbetslivet, Lund: Studentlitteratur.

Kjellberg, A. (2018). Kollektivavtalens täckningsgrad samt organisationsgraden hos arbetsgivarförbund och fackförbund [Collective agreements' coverage and organization rate among the employers' and unions' organizations], (1 red.). Studies in Social Policy, Industrial Relations, Working Life and Mobility. Research Reports; Vol. 2018:1, Lund: Department of Sociology, Lund University.

Lind, J. (2007). A Nordic saga? The Ghent system and trade unions, International Journal of Employment Studies 15(1): 49-68.

Lindellee, J. (2018). Beyond Retrenchment: Multi-Pillarization of Unemployment Benefit Provision in Sweden, Lund: Socialhögskolan, Lunds universitet.

Lindquist, G.S. \& Wadensjö, E. (2011). Avtalsbestämda ersättningar, andra kompletterande ersättningar och arbetsutbudet [Collective agreement-based benefits, other complementary benefits and labor supply], Rapport till Expertgruppen för studier i offentlig ekonomi 2011:4, Stockholm: Finansdepartementet, Regeringskansliet.

Lindvall, J. \& Sebring, J. (2005). Policy reform and the decline of corporatism in Sweden, West European Politics 28(5): 1057-1074. doi: https://doi.org/10.1080/01402380500311814.

Martinson, S. (2005). Omställningsavtalen: mellan vilka, för vilka och på vilket sätt? [Employment Transition Agreements: between whom, for whom and how?] Rapport 2005:15, Uppsala: Institutet för arbetsmarknads- och utbildningspolitisk utvärdering (IFAU).

Promemoria (2014). Höjd inkomstrelaterad ersättning i arbetslöshetsförsäkringen. [Raised income-related benefits in unemployment insurance program.] 2014-10-09. Arbetsmarknadsdepartementet, Regeringskansliet.

Prop. (2006/07:15). En arbetslöshetsförsäkring för arbete. [An unemployment insurance program for work].

Prop. (2013/14:1). Budgetpropositionen för 2014. [Budget proposal for 2014].

Prop. (2014/15:99). Vårändringsbudget för 2015. [Budget modification for Spring 2015].

Rasmussen, M.B. \& Pontusson, J. (2018). Working-class strength by institutional design? unionization, partisan politics, and unemployment insurance systems, 1870 to 2010, Comparative Political Studies 51(6): 793-828. doi: https://doi.org/10.1177/0010414017710269.

Rathgeb, P. (2018). Strong Governments, Precarious Workers: Labor Market Policy in the Era of Liberalization, Ithaca, NY: Cornell University Press.

Rothstein, B. (1992). Labor market institutions and working-class strength. In: Steinmo, S., Thelen, K. \& Longstreth, F. (eds) Structuring Politics: Historical Institutionalism in Comparative Analysis, Cambridge: Cambridge University Press.

Rothstein, B. \& Bergström, J. (1999). Korporatismens fall och den svenska modellens Kris. [The fall of corporatism and the crisis of Swedish model], Stockholm: SNS Förlag.

SCB (2017). Lönespridning efter sektor och kön 2017, Lönestrukturstatistik. [The spread of wages across sectors and sex 2017, Statistics on wage structure] Statistiska centralbyrån.

Scruggs, L. (2002). The Ghent system and union membership in Europe, 1970-1996, Political Research Quarterly 55(2): 275-297. doi: https://www.jstor.org/stable/3088053.

Scruggs, L. (2007). Welfare state generosity across space and time. In: Clasen, J. \& Siegel, N.A. (eds) Investigating Welfare State Change. The 'Dependent Variable Problem' in Comparative Analysis, Cheltenham: Edward Elgar. 
Sebardt, G. (2005). Redundancy and the Swedish Model: Swedish Collective Agreements on Employment Security in a National and International Context. PhD dissertation, Uppsala: Iustus förlag.

SFS (1997:238). Lag (1997:238). om arbetslöshetsförsäkring. [Law on unemployment insurance].

Sjöberg, O. (2011). Sweden: ambivalent adjustment. In: Clasen, J. \& Clegg, D. (eds) Regulating the Risk of Unemployment: National Adaptations to Post-industrial Labour Markets in Europe, Oxford: Oxford University Press. doi: 10.1093/acprof:oso/9780199592296.001.0001.

Sjöberg, O.,Palme, J. \& Carroll,E. (2010).Unemployment Insurance.In: Castles, F.G.,Leibfried, S., Lewis, J., Obinger, H. \& Pierson, C. (eds) The Oxford Handbook of The Welfare State, Oxford: Oxford University Press. doi: 10.1093/oxfordhb/9780199579396.001.0001.

SOU (2015:21). 'Mer trygghet och bättre försäkring', Slutbetänkande av Parlamentariska socialförsäkringsutredningen, Del 2. [More security and better insurance. Final statement of parliamentary investigation of social insurances] Stockholm: Statens offentliga utredningar.

Thelen, K. \& Mahoney, J. (2010). A Theory of Gradual Institutional Change. In: Thelen, K. \& Mahoney, J. (eds) Explaining Institutional Change, Ambiguity, Agency, and Power, Cambridge University Press.

Timonen, V. (2003). Restructuring the Welfare State. Globalization and Social Policy Reform in Finland and Sweden, Cheltenham: Edward Elgar.

Trampusch, C. (2007). Industrial relations as a source of solidarity in times of welfare state retrenchment, Journal of Social Policy 36(2): 197-215. doi: https://doi.org/10.1017/ $\underline{\text { S0047279406000560. }}$.

Trampusch, C. (2013). Employers and collectively negotiated occupational pensions in Sweden, Denmark and Norway: Promoters, vacillators and adversaries, European Journal of Industrial Relations 19(1): 37-53. doi: https://doi.org/10.1177/0959680112474882.

van Rie, T., Marx, I. \& Horemans, J. (2011). Ghent revisited: Unemployment insurance and union membership in Belgium and the Nordic countries, European Journal of Industrial Relations 17(2): 125-139. doi: https://doi.org/10.1177/0959680111400895.

Vedin, U. (2014). Hur blev det med det kompletterande försäkringsskyddet? En utvärdering av LO-förbundens inkomstförsäkringar 2007 till 2010 [How did it turn out for the complementary insurance protection? An evaluation of the LO federations' income insurance schemes 2007- to 2010], Enheten för ekonomisk politik och arbetsmarknad. Landsorganisationen i Sverige. Unpublished report.

Walter, L. (2015). Mellan jobb: Omställningsavtal och stöd till uppsagda i Sverige. [Between jobs: Transition agreements and supports for the unemployed in Sweden.], Stockholm: SNS Förlag.

Weaver, R.K. (1988). Automatic Government. The Politics of Indexation, Washington: The Brookings Institution.

Western, B. (1997). Between Class and Market: Postwar Unionization in the Capitalist Democracies, New Jersey: Princeton University Press.

\section{Notes}

${ }^{1}$ Although the Ghent system originated in a town called Ghent in Belgium, in Belgium, it transformed into a compulsory insurance system in 1944. However, the system is still considered a 'partial Ghent system', as the unions are extensively involved in benefit payments (van Rie et al. 2011). 
${ }^{2}$ In Swedish, they are often called trygghetsavtal or omställningsavtal. There is yet no widely accepted single term for indicating these collective agreements. For the English translation, I use the term Employment Transitional Agreements used by several Swedish researchers having published recently on the topic, such as Jansson et al. $(2016,2018)$.

${ }^{3}$ I use the term complementary income insurance, while in Swedish it is often referred to as inkomstförsäkring. I choose to add the word 'complementary' consistently in order to make its role clear.

${ }^{4}$ Utjämningsavgift in Swedish. Different authors use different English terms such as 'balancing fee' (Bandau 2017, p. 19) or 'equalization fund' (Gordon 2017. p. 13).

5 The Alliance government abolished differentiated membership fees for unemployment insurance funds beginning in January 2014 (Prop., 2013/14:1: 20-21) and the fee levels have subsequently converged again, ranging between SEK 100 and SEK 130 in 2016.

${ }^{6}$ Swedish Confederation of Professional Associations (Sveriges akademikers centralorganisation)

${ }^{7}$ Swedish Confederation of Professional Employees (Tjänstemännens centralorganisation)

${ }^{8}$ Swedish Trade Union Confederation (Landsorganisation)

${ }^{9}$ SEK 100 is equivalent to EUR 9.3

${ }^{10}$ See, for instance, Bromander (2017) for the role of income insurance in membership increase among the TCO unions. 